\title{
Lactococcus lactis ssp. lactis as Potential Functional Starter Culture
}

\author{
Jadranka Frece*, Jelena Curtila, Ivana Topić, Frane Delaš and Ksenija Markov \\ Laboratory for General Microbiology and Food Microbiology, Department of Biochemical Engineering, \\ Faculty of Food Technology and Biotechnology, University of Zagreb, Pierottijeva 6, HR-10000 Zagreb, Croatia \\ Received: July 3, 2014 \\ Accepted: October 20, 2014
}

\begin{abstract}
Summary
The aim of this study is to identify and characterise potential autochthonous functional starter cultures in homemade horsemeat sausage. The dominant microflora in the samples of horsemeat sausage were lactic acid bacteria (LAB), followed by micrococci. Among the $\mathrm{LAB}$, Lactococcus lactis ssp. lactis and Lactobacillus plantarum were the dominant species, and since the first is not common in fermented sausages, we characterised it as a potential functional starter culture. Lactococcus lactis ssp. lactis produced a significant amount of lactic acid, displayed good growth capability at 12,18 and $22{ }^{\circ} \mathrm{C}$, growth in the presence of 5 $\% \mathrm{NaCl}$, good viability after lyophilisation and in simulated gastric and small intestinal juice, antimicrobial activity against test pathogens, and good adhesive properties in vitro.
\end{abstract}

Key words: horsemeat sausages, in vitro adhesion, natural microflora, technological and functional characterisation

\section{Introduction}

Lactic acid bacteria (LAB) are natural food preservatives that have been Generally Recognized as Safe (GRAS) by the US Food and Drug Administration (FDA). Their benefits have been known since ancient times, and modern science has confirmed their positive effects on human intestinal microflora, including resistance to infectious diseases, immunomodulatory action, and digestion of lactose (1).

Considering their benefits, $\mathrm{LAB}$ have a great potential for application in functional foods (2). In meat preservation and fermentation, LAB are considered technologically fundamental. They decrease $\mathrm{pH}$ with lactic acid, produce bacteriocins that prevent the growth of pathogenic and spoilage microorganisms, modify sensory properties (flavour, colour and texture) of raw material, and improve the safety, stability and shelf-life of meat products $(2,3)$.

Naturally fermented sausage products are considered to be of higher quality than sausages whose fermentation is controlled with industrial starters (4). Many authors support the view that indigenous microflora or microorganisms found in traditional sausages originate from raw materials or the manufacturing environment $(5,6)$. This microbiota is commonly known as the house flora (7).

More and more research is focused on the isolation and identification of autochthonous functional starter cultures with the aim of developing new functional meat products that will be recognised and labelled as autochthonous to the region in which they are produced $(8,9)$.

The aim of this study is to identify and characterise microbial population, LAB in particular, naturally present in homemade horsemeat sausages from Pakrac (Slavonija, eastern Croatia). We also wanted to investigate the technological and functional properties and adhesion ability of the dominant bacterial strain in the intestinal epithelial cells of mice in vitro to see its potential as a starter culture for industrial production.

\section{Materials and Methods}

All experiments were carried out on five samples of homemade horsemeat sausage. The sausages had been prepared according to a traditional recipe without the use of industrial starters or any additives such as nitrites or 
ascorbic acid. The stuffing consisted of horsemeat (75\%), pork back fat (25\%), and seasoning (kitchen salt, pepper, paprika and garlic). The sausages were smoked for 2-3 days and then left to ripen in the ripening chamber until day 42. Samples were taken at the end of the ripening stage.

\section{Isolation and identification of microbial population}

To isolate and identify the microbial population in the sausages we used classical microbiological procedures and biochemical analytical profile index (API) methods, as well as random amplification of polymorphic DNA polymerase chain reaction (RAPD PCR) analysis for genetic fingerprinting. A mass of $10 \mathrm{~g}$ of each sample was homogenised in $90 \mathrm{~mL}$ of sterile $0.5 \% \mathrm{NaCl}$ solution and serially diluted before plating on selective and non-selective media as shown in Table 1.

Table 1. Classical microbiological methods for the isolation and identification of natural microbial populations

\begin{tabular}{llc}
\hline Microorganism & Nutrient medium & $\begin{array}{c}\text { Incubation } \\
\text { condition }\end{array}$ \\
\hline Lactic acid bacteria & $\begin{array}{l}\text { MRS agar (Biolife, Italy) } \\
\text { Yeasts }\end{array}$ & $30^{\circ} \mathrm{C} / 48-72 \mathrm{~h}$ \\
Micrococcus sp. & $\begin{array}{l}\text { Mabouraud agar (Biolife, Italy) } \\
\text { (bioMérieux, France) }\end{array}$ & $25^{\circ} \mathrm{C} / 48-72 \mathrm{~h}$ \\
\hline
\end{tabular}

One hundred and fifty colonies taken at random from selective plates were identified on the basis of colony morphology, Gram staining, cell morphology and catalase reaction. Genomic DNA was isolated from $1.5 \mathrm{~mL}$ of overnight cultures using the method described elsewhere $(2,10)$, which is a modification of the salting-out procedure described by Miller et al. (11). The extracted DNA was then used as a template in subsequent PCR reactions, which were performed according to Gardiner et al. (12). PCR amplifications were performed in a thermal cycler (Eppendorf Mastercycler ${ }^{\circledR}$ Personal, Hamburg, Germany) using 0.2-mL Eppendorf tubes for a total volume of $50 \mu \mathrm{L}$. PCR mixtures contained $1 \mu \mathrm{L}$ of template DNA, $1 \times$ Taq polymerase buffer (Fermentas, Pittsburgh, PA, USA), 4 $\mathrm{mmol} / \mathrm{L}$ of $\mathrm{MgCl}_{2}, 0.2 \mathrm{mmol} / \mathrm{L}$ of deoxynucleoside triphosphate (Fermentas), 5 U of Taq DNA polymerase (Fermentas), and two primers (5'ACGAGGCAC3' and 5'ACGCGCCCT3'), each at a concentration of $1 \mu \mathrm{mol} / \mathrm{L}$. DNA was amplified in 40 cycles using the following temperature profile: denaturation at $94{ }^{\circ} \mathrm{C}$ for $30 \mathrm{~s}$, annealing at $36^{\circ} \mathrm{C}$ for $30 \mathrm{~s}$, and polymerisation at $72{ }^{\circ} \mathrm{C}$ for $2 \mathrm{~min}$. The initial denaturation was performed at $94{ }^{\circ} \mathrm{C}$ for $5 \mathrm{~min}$, and the final extension step at $72{ }^{\circ} \mathrm{C}$ for $10 \mathrm{~min}$. The PCR products (10 $\mu \mathrm{L}$ of each reaction mixture) were analysed on a $1.5 \%$ (by mass per volume) agarose gel with $1 \times$ TBE buffer (89 mM Tris, $89 \mathrm{mM}$ boric acid, 2 mM EDTA) and ethidium bromide staining. The DNA of bacteriophage $\lambda$ cut with HindIII was used as molecular size standard.

\section{Storing conditions}

The dominant bacterial strain (isolated from horsemeat sausages) was stored at $-70{ }^{\circ} \mathrm{C}$ in the M17 broth (Difco, Detroit, MI, USA) with $30 \%$ (by volume) glycerol and kept with the culture collection of the Department of Biochemical Engineering, Laboratory for General Microbiology and Food Microbiology, University of Zagreb, Zagreb, Croatia, until further investigation.

\section{Effects of $\mathrm{NaCl}$ and temperature on microbial growth and proteolytic activity}

The effect of $5 \% \mathrm{NaCl}$ on the viability and proteolytic activity of the dominant LAB strain at different incubation temperatures $\left(12,18\right.$ and $\left.22{ }^{\circ} \mathrm{C}\right)$ was tested according to Bonomo et al. (13) and Babić et al. (8).

\section{Antibiotic resistance of lactobacilli}

The antibiotic resistance of the dominant LAB was tested on the MRS agar (Biolife, Milan, Italy) using the agar disc diffusion method as described by Babić et al. (8). The strains were classified as resistant or sensitive after incubation at $37^{\circ} \mathrm{C}$ for $18 \mathrm{~h}$. The following antibiotic discs (BD-Becton, Dickinson and Company, Franklin Lakes, New Jersey, MD, USA) were used: clindamycin (2 $\mu \mathrm{g})$; methicillin, neomycin and erythromycin (5 $\mu$ g each); tobramycin, ampicillin and lincomycin (10 $\mu \mathrm{g}$ each); gentamycin, chloramphenicol, rifampicin, vancomycin and tetracycline (30 $\mu$ g each).

\section{Preparation of simulated gastric and small intestinal juice}

Gastric and small intestinal juice simulations were prepared according to Kos et al. (14) with small modifications.

Simulated gastric juice was prepared by suspending pepsin $(3 \mathrm{~g} / \mathrm{L})$ in a sterile sodium chloride solution $(0.5 \%)$ and adjusting the $\mathrm{pH}$ to 2 with concentrated $\mathrm{HCl}$. Pepsin (from porcine stomach mucosa) was obtained from Sigma Chemical Co, St. Louis, MO, USA.

Simulated small intestinal juice was prepared by suspending pancreatin $(1 \mathrm{~g} / \mathrm{L})$ and bile salts $(2 \mathrm{mg} / \mathrm{mL}$ of oxgall) in a sterile sodium chloride solution $(0.5 \%)$ and adjusting the $\mathrm{pH}$ to 8.0 with $0.1 \mathrm{~mol} / \mathrm{L}$ of $\mathrm{NaOH}$. Pancreatin (from hog pancreas, $165 \mathrm{U} / \mathrm{mg}$ ) was obtained from Fluka Biochemica, Buchs, Switzerland, and oxgall (dehydrated fresh bile) from Difco Laboratories, Detroit, MI, USA.

\section{Survival of the dominant $L A B$ in gastric and small intestinal juice simulations}

Washed cell suspensions of the dominant LAB (0.2 $\mathrm{mL}$ ) were vortexed separately with gastric and small intestinal juice $(1 \mathrm{~mL})$ and $0.3 \mathrm{~mL}$ of $0.5 \% \mathrm{NaCl}$. Changes in total viable count were monitored during treatment with gastric $(2 \mathrm{~h})$ and small intestinal juice $(4 \mathrm{~h})$ using the pour plate method. The plates with MRS were incubated at 37 ${ }^{\circ} \mathrm{C}$ for $4 \mathrm{~h}$. The $\log \mathrm{CFU} / \mathrm{mL}$ is expressed as percentage of LAB viability.

\section{Determination of lactic acid production by HPLC}

Lactic acid produced in the samples was determined using high performance liquid chromatography (HPLC) according to Babić et al. (8), and the results were expressed as $\mathrm{g} / \mathrm{L}$. Glucose, lactic acid, acetate, and ethanol for stan- 
dard solutions were obtained from Sigma-Aldrich (Bellefonte, PA, USA). A solution of $\mathrm{H}_{3} \mathrm{PO}_{4}$ (85\%, by volume) (Sigma-Aldrich, Hamburg, Germany) was used to prepare the mobile phase $\left(\mathrm{H}_{3} \mathrm{PO}_{4} 0.1 \%\right.$, by volume), and deionized water with conductivity $<1 \mu \mathrm{S}$ to prepare the mobile phase and standard solutions. Chromatographic analysis was performed using a Shimadzu Class-VPTM LC-10A $\mathrm{AP}_{\mathrm{VP}}$ system (Shimadzu, Kyoto, Japan). The mobile phase flow rate of the Piston pump $\left(\mathrm{LC}-10 \mathrm{AD}_{\mathrm{VP}}\right)$ was $0.5 \mathrm{~mL} / \mathrm{min}$. The substrate and the product were separated on a Supelcogel $^{\mathrm{TM}} \mathrm{C}-610 \mathrm{H}$ analytical column $(30 \mathrm{~cm} \times 7.8 \mathrm{~mm}$ i.d., $9 \mu \mathrm{m}$ particle size) and a Supelcogel ${ }^{\mathrm{TM}} \mathrm{H}$ guard column $(5 \mathrm{~cm} \times$ $4.6 \mathrm{~mm}$ i.d., $9 \mu \mathrm{m}$ particle size), both supplied by SigmaAldrich, Hamburg, Germany, and detected using the refractive index detector (RID-10A).

\section{Antibacterial activity}

Antibacterial activity of the dominant LAB isolate was tested using the turbidimetric method (8) by comparing the growth of test microorganisms in nutrient broth (beef extract $3 \%$, by mass, peptone $5 \%$, by mass; Biolife, Milano, Italy) at $37^{\circ} \mathrm{C}$ over $72 \mathrm{~h}$ with and without the LAB isolate. The results were expressed as growth inhibition of the following test microorganisms: Staphylococcus aureus 3048, Escherichia coli 3014, Salmonella sp. 3064 and Listeria monocytogenes ATCC 23074 (Collection of Microorganisms of the Laboratory for General Microbiology and Food Microbiology, Faculty of Food Technology and Biotechnology, University of Zagreb, Zagreb, Croatia).

\section{In vitro adhesion test}

The adhesion test was performed using the method of Marteau et al. (15) with some modifications (1). Ileal samples were collected from three-month-old Swiss albino mice obtained from the Rijeka University School of Medicine, Rijeka, Croatia. The tissues were held in phosphate-buffered saline (PBS) at $4{ }^{\circ} \mathrm{C}$ for $30 \mathrm{~min}$ to loosen the surface mucus and then washed three times with PBS. The adhesion test was performed by incubating tissue samples $\left(1 \mathrm{~cm}^{2}\right)$ in bacterial suspensions $\left(10^{9} \mathrm{cell} / \mathrm{mL}\right.$ of PBS $)$ at 37 ${ }^{\circ} \mathrm{C}$ for $30 \mathrm{~min}$. Samples of ileum were fixed in $10 \%$ formalin, dehydrated with increasing concentrations of ethanol, and embedded in paraffin. Serial sections $(5 \mu \mathrm{m})$ were cut, mounted on standard microscope slides, and stained for identification of Gram-positive and Gram-negative bacteria according to Frece et al. (1). The slides were examined and photographed using a Nikon Mikrophot-FXA light microscope (Nikon, Tokyo, Japan). All experimental procedures complied with the standards set out in the Guide for the Care and Use of Laboratory Animals of the National Research Council (16). The best of the three photographs is presented in the results.

\section{Viability of the dominant $L A B$ strain during lyophilisation and storage}

The strain was cultivated in MRS broth overnight. The cells were collected by centrifugation $(8000 \times g$ for 20 min), washed, resuspended in skimmed milk (10\%, by mass per volume), and frozen at $-20{ }^{\circ} \mathrm{C}$ overnight, then lyophilised in a bench top freeze dryer (model Christ Alpha 1-4, B. Braun Biotech International, Melsungen, Germany). The lyophilised cells were stored at $-20{ }^{\circ} \mathrm{C}$ for six months. The recovery of viable cells was determined by colony formation on MRS agar using the standard pour plating method. The log CFU/mL is expressed as percentage of viability (17).

\section{Statistical analysis}

All experiments were carried out in triplicate. The results are expressed as mean value \pm standard deviation (S.D.). Apart from descriptive statistics, no other analysis was done, as it was not necessary for the scope and objective of our study.

\section{Results and Discussion}

Our microbiological analysis showed that the dominant microflora in the horsemeat sausage samples were $\mathrm{LAB}$, followed by micrococci and yeasts (Table 2). Like $\mathrm{LAB}$, micrococci contribute to the colour and flavour of the sausage, but unlike $L A B$, they are not directly involved in fermentation.

Our finding of the yeasts Candida zeylanoides and Geotrichum candidum is in agreement with the findings of Nielsen et al. (18). Yeasts also play an important role in the maturation of sausages, since they contribute to the development of sensory characteristics of fermented sausages due to their lipolytic and proteolytic activity $(19,20)$.

With API 50 CHL identification kits (bioMérieux, Lyon, France) we were able to classify 100 colonies randomly taken from the MRS agar into four main bacterial

Table 2. Microbiological and biochemical identification of natural microbial populations in horsemeat sausage samples

\begin{tabular}{|c|c|c|c|c|}
\hline \multirow{2}{*}{ Microorganism } & \multirow{2}{*}{$N($ sample $)$} & $N($ microorganism) & \multirow{2}{*}{ API test } & \multirow{2}{*}{$N($ sample $)$} \\
\hline & & $\log \mathrm{CFU} / \mathrm{g}$ & & \\
\hline \multirow{4}{*}{ Lactic acid bacteria } & \multirow{4}{*}{5} & \multirow{4}{*}{$(7.5-9.3) \pm 1.3$} & L. lactis ssp. lactis & 5 \\
\hline & & & L. plantarum & 4 \\
\hline & & & L. delbrueckii & 1 \\
\hline & & & L. acidophilus & 2 \\
\hline Micrococcus sp. & 5 & $(2.7-3.4) \pm 1.5$ & Micrococcus sp. & \\
\hline \multirow{2}{*}{ Yeasts } & \multirow{2}{*}{5} & \multirow{2}{*}{$(4.4-5.0) \pm 1.3$} & Candida zeylanoides & 5 \\
\hline & & & Geotrichum candidum & 1 \\
\hline
\end{tabular}

Results are the mean value \pm S.D. of triplicate assays 
species and 16 strains (the API test precision was 97-99.9 $\%)$, and the dominant microflora were $\mathrm{LAB}$, which were then confirmed by the RAPD PCR analysis.

Altogether four species were identified: Lactococcus lactis ssp. lactis, Lactobacillus plantarum, Lactobacillus delbrueckii and Lactobacillus acidophilus, and each consisted of four strains. Each of the four strains of a species had identical RAPD fingerprints (Fig. 1). The most dominant LAB species was Lactococcus lactis ssp. lactis, as it was isolated from all five sausage samples, followed by Lactobacillus plantarum, isolated from four samples (Table 3).

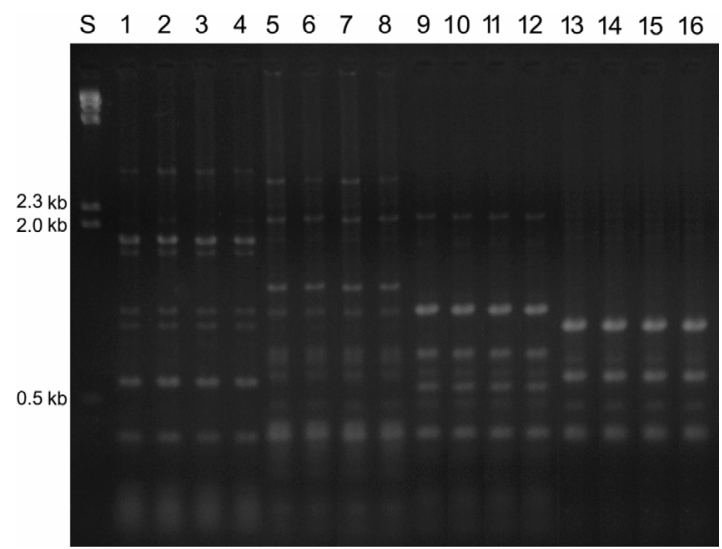

Fig. 1. Random amplification of polymorphic DNA (RAPD) fingerprints of lactic acid bacteria. Lanes 1-4: Lactobacillus acidophilus, lanes 5-8: Lactobacillus delbrueckii, lanes 9-12: Lactobacillus plantarum, lanes 13-16: Lactococcus lactis ssp. lactis, lane S: molecular size standard

Table 3. Lactic acid bacteria (LAB) isolates in samples of homemade horsemeat sausage

\begin{tabular}{ccccc}
\hline \multirow{5}{*}{$\begin{array}{c}\text { N(LAB) } \\
\text { (sample) }\end{array}$} & \multicolumn{5}{c}{$\log$ CFU/g } \\
\cline { 2 - 5 } & $\begin{array}{c}\text { L. lactis } \\
\text { ssp. lactis }\end{array}$ & $\begin{array}{c}\text { L. } \\
\text { plantarum }\end{array}$ & $\begin{array}{c}\text { L. } \\
\text { delbrueckii }\end{array}$ & $\begin{array}{c}\text { L. } \\
\text { acidophilus }\end{array}$ \\
\hline 1 & $8.3 \pm 1.1$ & - & $1.0 \pm 0.8$ & - \\
2 & $5.8 \pm 1.2$ & $3.7 \pm 1.2$ & - & - \\
3 & $4.0 \pm 1.1$ & $3.3 \pm 1.3$ & - & $2.0 \pm 1.3$ \\
4 & $4.3 \pm 1.2$ & $3.0 \pm 1.1$ & - & - \\
5 & $4.5 \pm 1.3$ & $2.5 \pm 0.9$ & - & $1.3 \pm 1.4$ \\
\hline
\end{tabular}

Results are the mean value \pm S.D. of triplicate assays

The dominance of Lactococcus lactis ssp. lactis in fermented sausage has rarely been reported so far. The metabolic properties of the L. lactis species have a direct or indirect effect on the organoleptic, nutritional and hygienic quality of fermented products (21). As in a preliminary research (disc diffusion method, data not shown) all Lactococcus isolates showed good antimicrobial properties, and our dominant isolate, Lactococcus lactis ssp. lactis excelled among them, we decided to further characterise it as a starter culture. Table 4 shows its technological and functional properties. Its outstanding ability to grow in the presence of $\mathrm{NaCl}$ at a range of concentrations and temperatures used in meat processing industry has already
Table 4. Technological and functional characteristics of Lactococcus lactis ssp. lactis

\begin{tabular}{lc}
\hline $\begin{array}{l}\text { Technological characteristics and } \\
\text { selection criteria }\end{array}$ & $\begin{array}{c}\text { Lactococcus lactis } \\
\text { ssp. lactis }\end{array}$ \\
\hline Growth in the presence of $5 \% \mathrm{NaCl}$ & + \\
Growth at $12{ }^{\circ} \mathrm{C}$ & + \\
Growth at $18{ }^{\circ} \mathrm{C}$ & + \\
Growth at $22{ }^{\circ} \mathrm{C}$ & + \\
Proteolytic activity & + \\
Homofermentative species & + \\
Catalase test & + \\
$\gamma($ lactic acid)/(g/L) & $43.83 \pm 0.21$ \\
pH of the medium & - \\
Antibiotic resistance & 51.24 \\
Viability in simulated gastric juice/\% & 71.53 \\
Viability in simulated small intestinal juice/\% & \\
Viability after lyophilisation (skimmed milk & 98.62 \\
used as lyoprotector)/\% &
\end{tabular}

+=yes, $-=$ no

been reported by Kim et al. (22) and Itoi et al. (23). In order to act as a probiotic in the gastrointestinal tract, the bacteria must be able to survive the acidic conditions of the stomach and resist the bile acids at the beginning of the small intestine $(1,2,24,25)$. The viability of our L. lactis isolate in simulated gastric juice $(\mathrm{pH}=2$, salt content $0.5 \%)$ was $51.24 \%$ (Table 4 ) after $2 \mathrm{~h}$ of exposure. Our results are in agreement with the report by Kimoto-Nira et al. (26), who found that L. lactis ssp. lactis was resistant to low $\mathrm{pH}$ and bile salts. In small intestinal juice, the viability of the isolate was $71.23 \%$ (Table 4 ), which is essential for its probiotic effects.

The production of lactic acid, which results in a decrease in $\mathrm{pH}$, contributes to the texture, colour and acidic taste, prevents the growth of pathogenic and spoilage microorganisms and improves the safety and stability of meat products (27). Our study has shown that L. lactis ssp. lactis is homofermentative. The concentration of lactic acid produced by homolactic fermentation of glucose was $13.83 \mathrm{~g} / \mathrm{L}$, and the medium was acidified to $\mathrm{pH}=4.16$ (28). In contrast, heterofermentative $\mathrm{LAB}$ are not suitable for sausage production because they produce large amounts of carbon dioxide that creates holes in the product. In addition, these LAB produce acetic acid, which causes a pungent off-flavour (27).

L. lactis ssp. lactis isolated in our study was catalase-positive and showed good proteolytic activity (Table 4), which is important in preventing rancidity and preserving meat colour. Another essential property for the probiotic activity of a functional starter culture is the competition with pathogens (29). Our L. lactis ssp. lactis isolate inhibited the growth of all test pathogens over $72 \mathrm{~h}$ of cultivation, as follows (in \%): E. coli 73.4-85.4, S. aureus 51.587.0, Salmonella spp. 62.7-88.6 and L. monocytogenes 61.0 82.4 (28). Antimicrobial properties of L. lactis ssp. lactis are of great importance for the application of this strain as functional starter culture in fermented meat products. 
One of the selection criteria for probiotic strains is the ability to adhere to the intestinal tract of the host. Good adhesion means that a probiotic strain will exert its properties better $(1,2)$. In this respect, our L. lactis ssp. lactis isolate showed very good adhesion (Fig. 2).

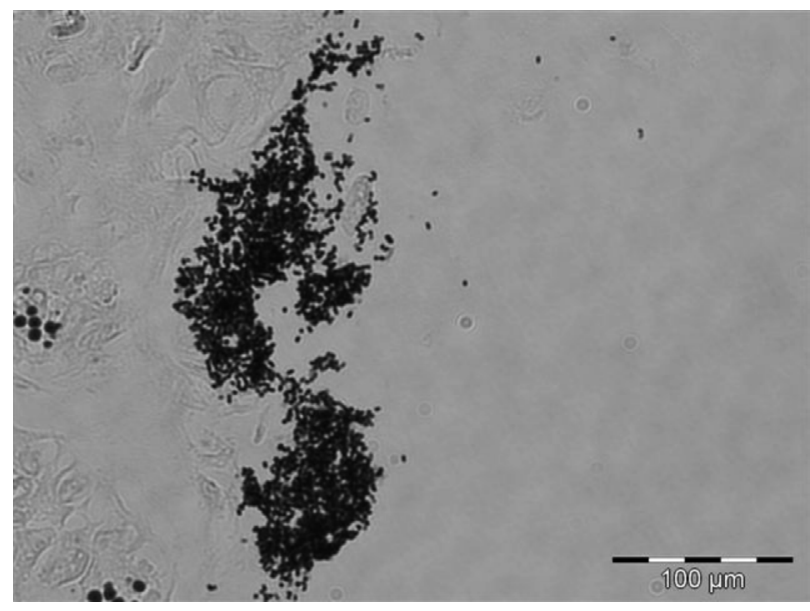

Fig. 2. Adhesion of Lactococcus lactis ssp. lactis to the large intestine of the mouse

Research during the last few decades has shown that starter cultures can develop resistance to clinically relevant antibiotics $(8,30)$. Our isolate, however, showed sensitivity to all 12 tested antibiotics: clindamycin, methicillin, neomycin, erythromycin, tobramycin, ampicillin, lincomycin, gentamycin, chloramphenicol, rifampicin, vancomycin and tetracycline (Table 4).

In industrial application, bacteria are subjected to stress that can lower their viability. Viability can be affected by harsh heat treatment, mechanical processing, storage at room temperature, food matrix, and chemical microenvironment (25). Furthermore, a range of processes has been used to obtain dry formulations with prolonged shelf-life, the most common being freeze drying, vacuum drying, and spray drying. These processes do osmotic damage to probiotic cells, and cell death usually correlates with cell membrane damage (17). The membrane is usually protected by cryoprotectants (against freezing) and lyoprotectants (against lyophilisation). These are small molecules or polymers with osmotic behaviour, which promote the formation of amorphous or glassy solids and reduce ice formation that can be cell-damaging (17). We protected our isolate cells with skimmed milk as lyoprotectant, and, judging by the high survival, they withstood well the stress associated with lyophilisation (Table 4).

\section{Conclusions}

The dominant LAB, Lactococcus lactis ssp. lactis, isolated from the horsemeat sausage in our study has shown good technological and functional properties important for starter cultures. It has also shown good survival in simulated gastrointestinal environment in vitro, desirable adhesive properties in intestinal epithelial cells of mice, and sufficient antimicrobial activity against pathogen microorganisms, which are all important properties for the selection of a probiotic starter culture. We therefore believe that it could be used for controlled fermentation of meat products.

This work can be considered preliminary, as it was conducted to characterise an autochthonous functional starter culture. Implementation of this culture in small- to medium-sized enterprises and industrial production should improve the quality, uniformity and safety of the final product. Hopefully, the product will meet all marketing regulations yet remain autochthonous and recognisable. Before that happens, further investigation is needed to confirm good adhesive properties and resilience to gastrointestinal environment in vivo. Our study is a contribution to an effort to create a bank of traditional and autochthonous functional starter cultures for wider and controlled use in the future.

\section{Acknowledgement}

This study was supported by Ministry of Science, Education and Sports of the Republic of Croatia (grant no. 058-0582184-0432). The authors wish to thank Mr Dado Čakalo for help in editing this article.

\section{References}

1. J. Frece, B. Kos, J. Beganović, S. Vuković, J. Šušković, In vivo testing of functional properties of three selected probiotic strains, World J. Microbiol. Biotechnol. 21 (2005) 1401-1408. http://dx.doi.org/10.1007/s11274-005-5741-8

2. J. Frece, B. Kos, I.K. Svetec, Z. Zgaga, J. Beganović, A. Leboš, J. Šušković, Synbiotic effect of Lactobacillus helveticus M92 and prebiotics on the intestinal microflora and immune system of mice, J. Dairy Res. 76 (2009) 98-104. http://dx.doi.org/10.1017/S0022029908003737

3. C. Fontana, P.S. Cocconcelli, G. Vignolo, Monitoring the bacterial population dynamics during fermentation of artisanal Argentinean sausages, Int. J. Food Microbiol. 103 (2005) 131142.

http://dx.doi.org/10.1016/j.ijfoodmicro.2004.11.046

4. I. Lebert, S. Leroy, P. Giammarinaro, A. Lebert, J.P. Chacornac, S. Bover-Cid et al., Diversity of microorganisms in the environment and dry fermented sausages of small traditional French processing units, Meat Sci. 76 (2007) 112-122. http://dx.doi.org/10.1016/j.meatsci.2006.10.019

5. G. Mauriello, A. Casaburi, G. Blaiotta, F. Villani, Isolation and technological properties of coagulase negative staphylococci from fermented sausages of Southern Italy, Meat Sci. 67 (2004) 149-158.

http://dx.doi.org/10.1016/j.meatsci.2003.10.003

6. K. Rantsiou, R. Urso, L. Iacumin, C. Cantoni, P. Cattaneo, G. Comi, L. Cocolin, Culture-dependent and -independent methods to investigate the microbial ecology of Italian fermented sausages, Appl. Environ. Microbiol. 71 (2005) 1977-1986. http://dx.doi.org/10.1128/AEM.71.4.1977-1986.2005

7. M. García-Varona, E.M. Santos, I. Jaime, J. Rovira, Characterisation of Micrococcaceae isolated from different varieties of chorizo, Int. J. Food Microbiol. 54 (2000) 189-195. http://dx.doi.org/10.1016/S0168-1605(99)00192-0

8. I. Babić, K. Markov, D. Kovačević, A. Trontel, A. Slavica, J. Đugum et al., Identification and characterization of potential autochthonous starter cultures from a Croatian brand product Slavonski kulen, Meat Sci. 88 (2011) 517-524. http://dx.doi.org/10.1016/j.meatsci.2011.02.003

9. R. Urso, G. Comi, L. Cocolin, Ecology of lactic acid bacteria in Italian fermented sausages: Isolation, identification and 
molecular characterization, Syst. Appl. Microbiol. 29 (2006) 671-680.

http://dx.doi.org/10.1016/j.syapm.2006.01.012

10. A.M. Martín-Platero, E. Valdivia, M. Maqueda, M. Martínez-Bueno, Fast, convenient, and economical method for isolating genomic DNA from lactic acid bacteria using a modification of the protein salting-out procedure, Anal. Biochem. 36 (2007) 102-104.

http://dx.doi.org/10.1016/j.ab.2007.03.010

11. S.A. Miller, D.D. Dykes, H.F. Polesky, A simple salting out procedure for extracting DNA from human nucleated cells, Nucleic Acid Res. 16 (1988) 1215. http://dx.doi.org/10.1093/nar/16.3.1215

12. G.E. Gardiner, C. Heinemann, A.W. Bruce, D. Beuerman, G. Reid, Persistence of Lactobacillus fermentum RC-14 and Lactobacillus rhamnosus GR-1 but not L. rhamnosus GG in the human vagina as demonstrated by randomly amplified polymorphic DNA, Clin. Diagn. Lab. Immunol. 9 (2002) 92-96. http://dx.doi.org/10.1128/CDLI.9.1.92-96.2002

13. M.G. Bonomo, A. Ricciardi, T. Zotta, E. Parente, G. Salzano, Molecular and technological characterization of lactic acid bacteria from traditional fermented sausages of Basilicata region (Southern Italy), Meat Sci. 80 (2008) 1238-1248. http://dx.doi.org/10.1016/j.meatsci.2008.05.032

14. B. Kos, J. Šušković, J. Goreta, S. Matošić, Effect of protectors on the viability of Lactobacillus acidophilus M92 in simulated gastrointestinal conditions, Food Technol. Biotechnol. 38 (2000) 121-127.

15. P. Marteau, M. Minekus, R. Havenaar, J.H.J. Huis In't Veld, H. Gyllenberg, The adherence of lactic acid bacteria in a dynamic model of the stomach and small intestine: Validation and effect of bile, J. Dairy Sci. 80 (1997) 1031-1037. http://dx.doi.org/10.3168/jds.S0022-0302(97)76027-2

16. Guide for the Care and Use of Laboratory Animals, National Research Council, National Academies Press, Washington, DC, USA (1996).

17. B. Kos, J. Šušković, J. Beganović, K. Gjuračić, J. Frece, C. Iannaccone, F. Canganella, Characterization of the three selected probiotic strains for the application in food industry, World J. Microbiol. Biotechnol. 24 (2008) 699-707. http://dx.doi.org/10.1007/s11274-007-9528-y

18. D.S. Nielsen, T. Jacobsen, L. Jespersen, A.G. Koch, N. Arneborg, Occurence and growth of yeasts in processed meat products - Implications for potential spoilage, Meat Sci. 80 (2008) 919-926.

http://dx.doi.org/10.1016/j.meatsci.2008.04.011

19. D. Alagić, L. Kozačinski, I. Filipović, N. Zdolec, M. Hadžiosmanović, B. Njari et al., Microbiological changes during ripening of fermented horsemeat sausages, Meso (Meat), 10 (2008) 200- 203 (in Croatian).
20. D. Kovačević: Chemistry and Technology of Meat and Fish, Faculty of Food Technology, Josip Juraj Strossmayer University of Osijek, Osijek, Croatia (2001) (in Croatian).

21. E.H.E. Ayad, A. Verheul, W.J.M. Engels, J.T.M. Wouters, G. Smit, Enhanced flavour formation by combination of selected lactococci from industrial and artisanal origin with focus on completion of a metabolic pathway, J. Appl. Microbiol. 9 (2001) 59-67. http://dx.doi.org/10.1046/j.1365-2672.2001.01219.x

22. W.S. Kim, J. Ren, N.W. Dun, Diferentiation of Lactococcus lactis subspecies lactis and subspecies cremoris strains by their adaptive response to stresses, FEMS Microbiol. Lett. 171 (1999) 57-65. http://dx.doi.org/10.1111/j.1574-6968.1999.tb13412.x

23. S. Itoi, T. Abe, S. Washio, E. Ikuno, Y. Kanomata, H. Sugita, Isolation of halotolerant Lactococcus lactis subsp. lactis from intestinal tract of coastal fish, Int. J. Food Microbiol. 121 (2008) 116-121. http://dx.doi.org/10.1016/j.ijfoodmicro.2007.11.031

24. S. Erkkilä, E. Petäjä, Screening of commercial meat starter cultures at low $\mathrm{pH}$ and in the presence of bile salts for potential probiotic use, Meat Sci. 55 (2000) 297-300. http://dx.doi.org/10.1016/S0309-1740(99)00156-4

25. L. Yonekura, H. Sun, C. Soukoulis, I. Fisk, Microencapsulation of Lactobacillus acidophilus NCIMB 701748 in matrices containing soluble fibre by spray drying: Technological characterization, storage stability and survival after in vitro digestion, J. Funct. Foods, 6 (2014) 205-214. http://dx.doi.org/10.1016/j.jff.2013.10.008

26. H. Kimoto-Nira, M. Kobayashi, M. Nomura, K. Sasaki, C. Suzuki, Bile resistance in Lactococcus lactis strains varies with cellular fatty acid composition: Analysis by using different growth media, Int. J. Food Microbiol. 131 (2009) 183188.

http://dx.doi.org/10.1016/j.ijfoodmicro.2009.02.021

27. M.S. Ammor, B. Mayo, Selection criteria for lactic acid bacteria to be used as functional starter cultures in dry sausage production: An update, Meat Sci. 76 (2007) 138-146. http://dx.doi.org/10.1016/j.meatsci.2006.10.022

28. K. Markov, J. Frece, D. Čvek, A. Trontel, A. Slavica, D. Kovačević, Dominant microflora of fermented horse meat sausages, Meso (Meat), 12 (2010) 217-221 (in Croatian).

29. J. Frece, K. Markov, D. Kovačević, Determination of indigenous microbial populations, mycotoxins and characterization of potential starter cultures in Slavonian kulen, Meso (Meat), 12 (2010) 92-98 (in Croatian).

30. S. Kastner, V. Perreten, H. Bleuler, G. Hugenschmidt, C. Lacroix, L. Meile, Antibiotic susceptibility patterns and resistance genes of starter cultures and probiotic bacteria used in food, Syst. Appl. Microbiol. 29 (2006) 145-155. http://dx.doi.org/10.1016/j.syapm.2005.07.009 